\title{
Profile of buparlisib and its potential in the treatment of breast cancer: evidence to date [Corrigendum]
}

\author{
Criscitiello C, Viale G, Curigliano G, et al. Profile of \\ buparlisib and its potential in the treatment of breast can- \\ cer: evidence to date. Breast Cancer (Dove Med Press). \\ 2018;10:23-29.
}

On page 23, Giuseppe Curigliano's affiliation was incorrcectly listed as European Institute of Oncology, Milan, Italy. It should be Department of Oncology and Hemato-Oncology, Division of Early Drug Development for Innovative Therapy, University of Milan, European Institute of Oncology, Milan, Italy.

Breast Cancer - Targets and Therapy is an international, peerreviewed open access journal focusing on breast cancer research, identification of therapeutic targets and the optimal use of preventative and integrated treatment interventions to achieve improved outcomes, enhanced survival and quality of life for the cancer patient
The manuscript management system is completely online and includes a very quick and fair peer-review system, which is all easy to use. Visit http://www.dovepress.com/testimonials.php to read real quotes from published authors. 